\title{
Induced Production of Methyl Bromodihydroxyphenyl Acetates by the Marine-Derived Fungus Aspergillus sp.
}

\author{
Alain Simplice Leutou, ${ }^{a}$ Keumja Yun, ${ }^{a}$ Jung Sook Kang, ${ }^{b}$ and Byeng Wha Son ${ }^{* a}$ \\ ${ }^{a}$ Department of Chemistry, Pukyong National University; Busan 608-737, Korea: and ${ }^{b}$ School of Dentistry, Pusan \\ National University; Yangsan, Gyeongnam 626-870, Korea. \\ Received December 6, 2012; accepted January 6, 2013
}

\begin{abstract}
The addition of metal bromides $\left(\mathrm{NaBr}\right.$ and $\left.\mathrm{CaBr}_{2}\right)$ during fermentation of a marine isolate of the fungus Aspergillus sp. induced production of two new brominated dihydroxyphenylacetic acid derivatives, methyl 2-(6-bromo-3,4-dihydroxyphenyl)acetate (1) and methyl 2-(2,5-dibromo-3,4-dihydroxyphenyl)acetate (2), and a known compound, 2-(3,4-dihydroxyphenyl)acetic acid (3). The structures of the two new compounds $(1,2)$ were assigned through the combination of spectroscopic data analyses and comparison with the spectral data of compound 3. Compounds 1-3 exhibited potent radical-scavenging activity against 1,1-diphenyl-2-picrylhydrazyl (DPPH) with $\mathrm{IC}_{50}$ values $(14.2,12.1,11.0 \mu \mathrm{M}$, respectively) demonstrating greater activity than the positive control (L-ascorbic acid; $\mathrm{IC}_{50}, 20.0 \mu \mathrm{M}$ ).
\end{abstract}

Key words Aspergillus; methyl 2-(bromodihydroxyphenyl)acetate; dihydroxyphenylacetic acid

Marine-derived microorganisms continue to attract attention as rich sources of structurally novel bioactive metabolites that are potential lead compounds for the development of new drugs. ${ }^{1,2)}$ When marine-derived microorganisms are cultured under saline conditions, they rarely produce interesting biological halogenated metabolites (e.g., salinosporamide $\mathrm{A},{ }^{3)}$ a highly potent inhibitor of the $20 \mathrm{~S}$ proteasome, and its halogenated derivatives ${ }^{4}$; cytotoxic halogenated polyenyl pyrroles, isorumbrin and bromoisorumbrin ${ }^{5)}$; the nematicidal and antimicrobial lachnumon and mycorrhizin A derivatives ${ }^{6}$; bromomyrothenone $\mathrm{B}^{7)}$; and the antibacterial chlorohydroaspyrones $\mathrm{A}$ and $\mathrm{B}^{8)}$ ). Encouraged by the detection of bioactive halogenated marine analogs, and in an effort to gain access to a wider cross-section of halogenated secondary metabolites, we manipulated fermentation of the marine-derived fungi Phoma herbarum, Penicilliun chrysogenum, Fusarium tricinctum, and Dothideomycete sp. by the addition of halide salts to their respective culture mediums. We detected the production of radical scavenging haloquinones (bromochlorogentisylquinones A and B) ${ }^{9)}$ halodiphenyl ethers, ${ }^{10)}$ antibacterial bromomethylchlamydosporols $\mathrm{A}$ and $\mathrm{B},{ }^{11)}$ and antibacterial and radical scavenging 5-bromotoluhydroquinone. ${ }^{12)}$ This report describes the production, isolation, identification, and radical scavenging activity of two new brominated dihydroxyphenylacetic acid derivatives (compounds $\mathbf{1}, 2$ ) and a known compound, 2-(3,4-dihydroxyphenyl)acetic acid (3). ${ }^{13)}$ TLC analysis showed that the composition of the extract derived from fermentation in the halide-enriched culture medium differed from that derived during halide-free culture fermentation. In addition to compound $\mathbf{3}$, in the former extract two other spots were detected by TLC analysis; these were subsequently purified by repeated silica gel flash chromatography ( $n$-hexane in ethyl acetate) and HPLC (octadecyl silica (ODS)-A, $\mathrm{MeOH}-$ $\left.\mathrm{H}_{2} \mathrm{O}\right)$ to yield the two new compounds $\mathbf{1}$ and $\mathbf{2}$.

Methyl 2-(6-bromo-3,4-dihydroxyphenyl)acetate (1) was isolated as a slightly yellow solid having the molecular formula $\mathrm{C}_{9} \mathrm{H}_{9} \mathrm{BrO}_{4}$, based on high resolution electron impact mass spectrometry (HR-EI-MS) and ${ }^{13} \mathrm{C}-\mathrm{NMR}$ analyses. The compound had isotopic clusters at $m / z 260\left[\mathrm{M}\left({ }^{79} \mathrm{Br}\right)\right]^{+}(17)$ and

The authors declare no conflict of interest.
$262\left[\mathrm{M}\left({ }^{81} \mathrm{Br}\right)\right]^{+}(17)$ with a ratio of $1: 1$ in the EI-MS, suggesting the presence of a single bromine atom. The IR spectrum of compound 1 exhibited bands characteristic of hydroxyl $\left(3307 \mathrm{~cm}^{-1}\right)$ and ester $\left(1732,1168,1010 \mathrm{~cm}^{-1}\right)$ functionalities. Detailed analyses of the ${ }^{1} \mathrm{H}$ - and ${ }^{13} \mathrm{C}-\mathrm{NMR}$ spectra of compound 1, including the distortionless enhancement by polarization transfer (DEPT) and 2D-NMR spectra, correlation spectroscopy (COSY), heteronuclear multiple quantum correlation (HMQC), and heteronuclear multiple bond coherence (HMBC), revealed signals attributable to a methyl ester $\left[\delta_{\mathrm{H}}\right.$ $3.79\left(3 \mathrm{H}, \mathrm{s}, 1-\mathrm{OCH}_{3}\right), \delta_{\mathrm{C}} 52.9\left(\mathrm{q}, 1-\mathrm{OCH}_{3}\right)$, and $\left.173.8(\mathrm{~s}, \mathrm{C}-1)\right]$, a methylene $\left[\delta_{\mathrm{H}} 3.67\left(2 \mathrm{H}, \mathrm{s}, \mathrm{H}_{2}-2\right)\right.$ and $\left.\delta_{\mathrm{C}} 40.9(\mathrm{t}, \mathrm{C}-2)\right]$, and 1,2,4,5-tetrasubstituted phenyl groups (Table 1 and supplementary information). The connection among the functional groups of compound $\mathbf{1}$ was achieved on the basis of HMBC. The key HMBC correlations (from $1-\mathrm{OCH}_{3}$ to $\mathrm{C}-1$; from $\mathrm{H}_{2}-2$ to $\mathrm{C}-1, \mathrm{C}-1^{\prime}, 2^{\prime}$, and $\mathrm{C}-6^{\prime}$; from $\mathrm{H}-2^{\prime}$ to $\mathrm{C}-2, \mathrm{C}-3^{\prime}, \mathrm{C}-4^{\prime}$, and C-6'; and from $\mathrm{H}-5^{\prime}$ to $\mathrm{C}-1^{\prime}, \mathrm{C}-3^{\prime}, \mathrm{C}-4^{\prime}$, and $\mathrm{C}-6^{\prime}$ ) showed the connection between $\mathrm{C}-2$ and $\mathrm{C}-1^{\prime}$ as well as the positions of the $6^{\prime}$-bromo and $3^{\prime}, 4^{\prime}$-dihydroxyl groups on the phenyl ring (Fig. S5 of supplementary information). These spectroscopic features revealed that compound $\mathbf{1}$ had the general structural features of 2-(3,4-dihydroylphenyl)acetic acid (3). ${ }^{13)}$ The NMR data for both compounds showed similar patterns, except for the appearance of additional proton and carbon signals corresponding to an oxymethyl group $\left[\delta_{\mathrm{H}} 3.79(3 \mathrm{H}, \mathrm{s}, 1-\mathrm{OMe})\right.$ and $\delta_{\mathrm{C}} 52.9$ (q, 1-OMe)], and the disappearance of a proton signal at C- 6 , which was changed from the $s p^{2}$-methine $\left[\delta_{\mathrm{H}} 6.63(1 \mathrm{H}\right.$,

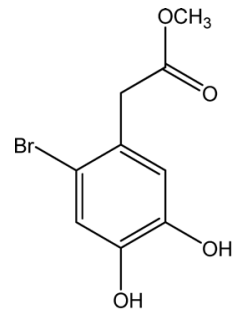<smiles>COC(=O)Cc1cc(Br)c(O)c(O)c1Br</smiles><smiles>O=C(O)Cc1ccc(O)c(O)c1</smiles>

Fig. 1. Structures of Compounds 1-3 
$\left.\mathrm{d}, J=7.5 \mathrm{~Hz}, \mathrm{H}-6^{\prime}\right)$ and $\left.\delta_{\mathrm{C}} 120.0\left(\mathrm{~d}, \mathrm{C}-6^{\prime}\right)\right]$ in compound 3 to the $s p^{2}$-quaternary carbon $\left[\delta_{\mathrm{C}} 114.4\left(\mathrm{~s}, \mathrm{C}-6^{\prime}\right)\right]$ in compound $\mathbf{1}$ (see Table 1 and supplementary information). Thus, compound 1 was identified as methyl 2-(6-bromo-3,4-dihydroxyphenyl)acetate.

Methyl 2-(2,5-dibromo-3,4-dihydroxyphenyl)acetate (2) was obtained in the form of a slightly yellow solid. It showed isotopic clusters at $\left.m / z 338\left[\mathrm{M}^{79} \mathrm{Br}_{2}\right)\right]^{+}(13), 340\left[\mathrm{M}\left({ }^{79} \mathrm{Br}\right.\right.$, $\left.\left.{ }^{81} \mathrm{Br}\right)\right]^{+}(24)$, and $342\left[\mathrm{M}\left({ }^{81} \mathrm{Br}_{2}\right)\right]^{+}(12)$ with a ratio of $1: 2: 1$ in the EI-MS, suggesting the presence of two bromine atoms. A molecular formula of $\mathrm{C}_{9} \mathrm{H}_{8} \mathrm{Br}_{2} \mathrm{O}_{4}$, which gave five degrees of unsaturation, was established by HR-EI-MS and ${ }^{13} \mathrm{C}-\mathrm{NMR}$. The IR spectrum of compound $\mathbf{2}$ exhibited band characteristics of hydroxyl $\left(3429 \mathrm{~cm}^{-1}\right)$ and ester $\left(1736,1137,1027 \mathrm{~cm}^{-1}\right)$ functionalities. The general features of the UV, IR, and NMR spectra closely resembled those of compound 1, except that one $s p^{2}$-methine proton in compound $\mathbf{1}$ was replaced with a bromine. The positions of the two bromines in compound 2 were determined by HMBC. The key HMBC correlations (from $1-\mathrm{OCH}_{3}$ to $\mathrm{C}-1$; from $\mathrm{H}_{2}-2$ to $\mathrm{C}-1, \mathrm{C}-1^{\prime}, 2^{\prime}$, and $\mathrm{C}-6^{\prime}$; and from $\mathrm{H}-6^{\prime}$ to $\mathrm{C}-2, \mathrm{C}-1^{\prime}, \mathrm{C}-2^{\prime}, \mathrm{C}-4^{\prime}$, and $\mathrm{C}-5^{\prime}$ ) showed the positions of the $2^{\prime}, 5^{\prime}$-dibromo and $3^{\prime}, 4^{\prime}$-dihydroxyl groups on the phenyl ring (Fig. S6 of supplementary information). Detailed analyses of the ${ }^{1} \mathrm{H}$ - and ${ }^{13} \mathrm{C}-\mathrm{NMR}$ spectra of compound 2 (including the results from DEPT, COSY, HMQC, and HMBC experiments) enabled its structure to be assigned as methyl 2-(2,5-dibromo-3,4-dihydroxyphenyl)acetate (see Table 1 and supplementary information).

The known 2-(3,4-dihydroxyphenyl)acetic acid (3) was also found during this study. It was identified from NMR spectra and from comparison with published data values. ${ }^{13)}$

There is considerable recent evidence that free radicals induce oxidative damage to biomolecules. This oxidative damage is considered to play a causative role in aging and several degenerative diseases such as Alzheimer's disease, rheumatoid arthritis, cancer, and atherosclerosis. ${ }^{14)}$ The antioxidant activity was assessed on the basis of the radical scavenging effect on the 1,1-diphenyl-2-picrylhydrazyl (DPPH) free radical. Compounds 1-3 exhibited significant radical scavenging activity against $\mathrm{DPPH}$ with $\mathrm{IC}_{50}$ values $(14.2,12.1,11.0 \mu \mathrm{M}$, respectively) demonstrating greater activity than the positive control (L-ascorbic acid; $\mathrm{IC}_{50}, 20.0 \mu \mathrm{M}$ ).

We plan to assess the inhibitory activity of compounds 1-3 against the epidermal growth factor receptor (EGFR), ${ }^{15,16)}$ and the results will be reported in due course.

\section{Experimental}

General UV/visible spectra were measured on a Hitachi U-2001 UV/Vis spectrometer. IR spectra were recorded on a Bruker FT-IR model IFS-88 spectrometer. ${ }^{1} \mathrm{H}-(400 \mathrm{MHz})$ and ${ }^{13} \mathrm{C}-\mathrm{NMR}(100 \mathrm{MHz})$ spectra were obtained on a JEOL JNMECP 400 NMR spectrometer, using TMS or solvent peaks [DMSO- $d_{6}:{ }^{1} \mathrm{H}(\delta 2.50)$ and $\left.{ }^{13} \mathrm{C}(\delta 39.5)\right]$ as reference standard. MS spectra were obtained on a JEOL JMS-700 spectrometer. HPLC was performed on a Young Lin ACME HPLC system using a reversed-phase analytical column (Gemini C18, $4.6 \times 250 \mathrm{~mm}, 5 \mu \mathrm{m})$ with UV detection. Incubations of microorganisms and feeding experiment were performed on an Incubator Shaker JS-FS-2500 (Johnsam Co., Inchon, Korea).

Fungal Isolation and Feeding Halide Salt The fungal strain was isolated from the surface of brown alga Ishige okamurae (Korean name: Pae) collected at Uljin, Korea in 2002, and identified to be Aspergillus sp. (gb/EU301661.1) on the basis of morphology and 18S ribosomal RNA (rRNA) analysis (SolGent Co., Ltd., Daejeon, Korea), identity of 98\%. A voucher specimen is deposited at Pukyong National University with the code MFB151. The fungus was cultured $(1 \mathrm{~L} \times 20)$ in SS medium consisting of soytone $(0.1 \%)$, soluble starch $(1.0 \%)$, and distilled water $(100 \%)$. The cultures $(1 \mathrm{~L} \times 20)$ were incubated at $29^{\circ} \mathrm{C}$ for $10 \mathrm{~d}$ on a rotary shaker $(120 \mathrm{rpm})$, and $\mathrm{NaBr}$ and $\mathrm{CaBr}_{2}$ (each $\left.50 \mathrm{~mm}\right)^{17,18)}$ was subsequently added to the each culture $(1 \mathrm{~L})$. All the cultures were incubated for a further $19 \mathrm{~d}$ under the same conditions. The culture control was incubated in the absence of metal halides $\left(\mathrm{NaBr}\right.$ and $\left.\mathrm{CaBr}_{2}\right)$ in the same manner as described above. TLC analysis showed that the composition of the extract differed from the extract derived from bromide-free SS medium.

Extraction and Isolation The mycelium and broth were separated by filtration through the cheesecloth, and the whole broth was extracted with EtOAc (20L) to afford broth extract $(1.2 \mathrm{~g})$. A portion of this extract $(1.0 \mathrm{~g})$ was subjected to $\mathrm{Si}$ gel flash chromatography. Elution was performed with $n$-hexaneEtOAc (stepwise, $0-100 \%$ EtOAc) to yield twenty collections $(50 \mathrm{~mL}$ each). These collections were pooled on the basis of their TLC profiles to give five combined fractions. Fractions 2 and 4 were separated by medium pressure liquid chromatography (MPLC) (ODS) using a $\mathrm{H}_{2} \mathrm{O}-\mathrm{MeOH}$ gradient elution to afforded crude compounds $\mathbf{1}, \mathbf{2}$, and $\mathbf{3}$, respectively. These were further purified by HPLC (Gemini C18, 4.6×250 mm, $1 \mathrm{~mL} / \mathrm{min}$ ) utilizing a $30 \mathrm{~min}$ gradient program of 50 to $100 \%$ $\mathrm{MeOH}$ in $\mathrm{H}_{2} \mathrm{O}$ to furnish compounds $\mathbf{1}(9 \mathrm{mg}), 2(7.5 \mathrm{mg})$, and $3(8 \mathrm{mg})$, respectively.

Table 1. NMR Spectral Data for Methyl 2-(6-Bromo-3,4-dihydroxyphenyl)acetate (1) and Methyl 2-(2,5-Dibromo-3,4-dihydroxyphenyl)acetate (2)

\begin{tabular}{|c|c|c|c|c|}
\hline \multirow{2}{*}{ Carbon No. } & \multicolumn{2}{|c|}{1} & \multicolumn{2}{|c|}{2} \\
\hline & $\delta_{\mathrm{H}}$ (mult., $J$ in $\mathrm{Hz}$ ) & $\delta_{\mathrm{C}}$ (mult.) & $\delta_{\mathrm{H}}$ (mult., $J$ in $\mathrm{Hz}$ ) & $\delta_{\mathrm{C}}$ (mult.) \\
\hline 1 & & $173.8(\mathrm{qC})$ & & $171.2(\mathrm{qC})$ \\
\hline 2 & $3.67(\mathrm{~s})$ & $40.9\left(\mathrm{CH}_{2}\right)$ & $3.70(\mathrm{~s})$ & $40.8\left(\mathrm{CH}_{2}\right)$ \\
\hline $1^{\prime}$ & & $125.2(\mathrm{qC})$ & & $127.2(\mathrm{qC})$ \\
\hline $2^{\prime}$ & $6.68(\mathrm{~s})$ & $118.0(\mathrm{CH})$ & & $111.6(\mathrm{qC})$ \\
\hline $3^{\prime}$ & & $144.1(\mathrm{qC})$ & & $141.9(\mathrm{qC})$ \\
\hline $4^{\prime}$ & & $143.8(\mathrm{qC})$ & & $140.8(\mathrm{qC})$ \\
\hline $5^{\prime}$ & $6.85(\mathrm{~s})$ & $119.4(\mathrm{CH})$ & & $108.2(\mathrm{qC})$ \\
\hline $6^{\prime}$ & & $114.4(\mathrm{qC})$ & $7.01(\mathrm{~s})$ & $125.5(\mathrm{CH})$ \\
\hline 1-OMe & $3.79(\mathrm{~s})$ & $52.9\left(\mathrm{CH}_{3}\right)$ & $3.73(\mathrm{~s})$ & $52.6\left(\mathrm{CH}_{3}\right)$ \\
\hline
\end{tabular}

a) Recorded in $\mathrm{CDCl}_{3}$ at $400 \mathrm{MHz}\left({ }^{1} \mathrm{H}\right)$ and $100 \mathrm{MHz}\left({ }^{13} \mathrm{C}\right)$. 
Methyl 2-(6-Bromo-3,4-dihydroxyphenyl)acetate (1): A slightly yellow solid; IR $(\mathrm{KBr}) v_{\max } 3307,1732,1621,1513$, $1452,1334,1168,1010,868,823 \mathrm{~cm}^{-1}$; UV $\lambda_{\max }(\mathrm{MeOH})(\log \varepsilon)$ 290 (3.44) nm; ${ }^{1} \mathrm{H}-\mathrm{NMR}\left(\mathrm{CDCl}_{3}, 400 \mathrm{MHz}\right)$ and ${ }^{13} \mathrm{C}-\mathrm{NMR}$ $\left(\mathrm{CDCl}_{3}, 100 \mathrm{MHz}\right)$ : see the Table 1; LR-EI-MS $\mathrm{m} / \mathrm{z}: 262$ $\left[\mathrm{M}\left({ }^{81} \mathrm{Br}\right)\right]^{+}(17), 260\left[\mathrm{M}\left({ }^{79} \mathrm{Br}\right)\right]^{+}(17), 203\left[\mathrm{M}\left({ }^{81} \mathrm{Br}\right)-\mathrm{CO}_{2} \mathrm{CH}_{3}\right]^{+}$ (87), $201 \quad\left[\mathrm{M}\left({ }^{79} \mathrm{Br}\right)-\mathrm{CO}_{2} \mathrm{CH}_{3}\right]^{+} \quad(88), \quad 181 \quad\left[\mathrm{M}\left({ }^{79} \mathrm{Br}\right)-{ }^{79} \mathrm{Br}\right]^{+}$ (100), 153 (26); HR-EI-MS m/z 259.9685 [M( $\left.\left.{ }^{79} \mathrm{Br}\right)\right]^{+}$(Calcd for $\left.\mathrm{C}_{9} \mathrm{H}_{9} \mathrm{O}_{4}{ }^{79} \mathrm{Br}, 259.9684\right) \quad(+0.4 \mathrm{ppm}) ; \mathrm{m} / \mathrm{z} 261.9663 \quad\left[\mathrm{M}\left({ }^{81} \mathrm{Br}\right)\right]^{+}$ (Calcd for $\left.\mathrm{C}_{9} \mathrm{H}_{9} \mathrm{O}_{4}{ }^{81} \mathrm{Br}, 261.9664\right)(-0.4 \mathrm{ppm})$.

Methyl 2-(2,5-Dibromo-3,4-dihydroxyphenyl)acetate (2): A slightly yellow solid; IR (KBr) $v_{\max } 3429,3234,2920$, $1736,1566,1472,1289,1137,1027,981,815,748 \mathrm{~cm}^{-1}$; UV $\lambda_{\max }(\mathrm{MeOH}) \quad(\log \varepsilon) 289.0 \quad(3.38) \quad \mathrm{nm} ;{ }^{1} \mathrm{H}-\mathrm{NMR} \quad\left(\mathrm{CDCl}_{3}\right.$, $400 \mathrm{MHz})$ and ${ }^{13} \mathrm{C}-\mathrm{NMR}\left(\mathrm{CDCl}_{3}, 100 \mathrm{MHz}\right)$ : see the Table 1; LR-EI-MS $\left.m / z: 342\left[\mathrm{M}^{81} \mathrm{Br}_{2}\right)\right]^{+}(12), 340\left[\mathrm{M}\left({ }^{79} \mathrm{Br},{ }^{81} \mathrm{Br}\right)\right]^{+}(24)$, $338\left[\mathrm{M}\left({ }^{79} \mathrm{Br}_{2}\right)\right]^{+}(13), 283\left[342-\mathrm{CO}_{2} \mathrm{CH}_{3}\right]^{+}(46), 281[340-$ $\left.\mathrm{CO}_{2} \mathrm{CH}_{3}\right]^{+}(100), 279\left[338-\mathrm{CO}_{2} \mathrm{CH}_{3}\right]^{+}(50), 261\left[342-{ }^{81} \mathrm{Br}\right]^{+}$ (68), 259 [338- $\left.{ }^{79} \mathrm{Br}\right]^{+}$(81), 199 (8), 203 (2), 201 (10), 180 (16); HR-EI-MS $m / z$ 337.8792 $\left[\mathrm{M}\left({ }^{79} \mathrm{Br}_{2}\right)\right]^{+}$(Calcd for $\mathrm{C}_{9} \mathrm{H}_{8} \mathrm{O}_{4}{ }^{79} \mathrm{Br}_{2}$, $337.8790)(+0.6 \mathrm{ppm}), \quad m / z \quad 339.8767 \quad\left[\mathrm{M}\left({ }^{79} \mathrm{Br},{ }^{81} \mathrm{Br}\right)\right]^{+}$(Calcd for $\left.\mathrm{C}_{9} \mathrm{H}_{8} \mathrm{O}_{4}{ }^{79} \mathrm{Br}^{81} \mathrm{Br}, 339.8769\right) \quad(-0.5 \mathrm{ppm}), \quad \mathrm{m} / \mathrm{z} \quad 341.8746$ $\left[\mathrm{M}\left({ }^{81} \mathrm{Br}_{2}\right)\right]^{+}$(Calcd for $\left.\mathrm{C}_{9} \mathrm{H}_{8} \mathrm{O}_{4}{ }^{81} \mathrm{Br}_{2}, 341.8748\right)(+0.7 \mathrm{ppm})$.

2-(3,4-Dihydroxyphenyl)acetic Acid (3): Spectroscopic data were virtually identical to those reported in the literature. ${ }^{13)}$

Radical Scavenging Activity against DPPH ${ }^{19}$ Samples (compounds 1-3, and positive control, L-ascorbic acid) to be tested were dissolved in $\mathrm{MeOH}$ and the solution $(160 \mu \mathrm{L})$ was dispensed into wells of a 96-well microtiter tray. Forty microliter of the DPPH solution in $\mathrm{MeOH}\left(1.5 \times 10^{-4} \mathrm{M}\right)$ was added to each well. The mixture was shaken and left to stand for $30 \mathrm{~min}$, and the absorbance of the resulting solution was measured at $520 \mathrm{~nm}$ with microplate reader (Packard Co., Spectra Count ${ }^{\mathrm{TM}}$ ). The scavenging activity on DPPH radical was expressed as $\mathrm{IC}_{50}$, which is the concentration of the tested compound required to give a $50 \%$ decrease of the absorbance from that of the blank solution [consisting of $\mathrm{MeOH}(160 \mu \mathrm{L})$ and DPPH solution $(40 \mu \mathrm{L})]$.

Acknowledgments This research was supported by the National Research Foundation of Korea Grant funded by the Korean Government (MOEHRD, Basic Research Promotion Fund) (KRF-2008-314-F00048). Mass spectral data were kindly provided by the Korea Basic Science Institute.

Supporting Information Available ${ }^{1} \mathrm{H}$ - and ${ }^{13} \mathrm{C}-\mathrm{NMR}$ and HMBC spectra of $\mathbf{1}$ and $\mathbf{2}$.

\section{References}

1) Blunt J. W., Copp B. R., Keyzers R. A., Munro M. H. G., Prinsep M. R., Nat. Prod. Rep., 29, 144-222 (2012).

2) Jensen P. R., Fenical W., "Marine Microorganisms and Drug Discovery: Current Status and Future Potential. Drugs from the Sea," ed. by Fusetani N., Karger, Basel, 2000, pp. 6-29.

3) Feling R. H., Buchanan G. O., Mincer T. J., Kaufman C. A., Jensen P. R., Fenical W., Angew. Chem. Int. Ed. Engl., 42, 355-357 (2003).

4) Lam K. S., Tsueng G., McArthur K. A., Mitchell S. S., Potts B. C. M., Xu J., J. Antibiot. (Tokyo), 60, 13-19 (2007).

5) Clark B. R., Lacey E., Gill J. H., Capon R. J., J. Nat. Prod., 70, 665-667 (2007).

6) Stadler M., Anke H., Sterner O., J. Antibiot. (Tokyo), 48, 149-153 (1995).

7) Li X., Zhang D., Lee U., Li X., Cheng J., Zhu W., Jung J. H., Choi H. D., Son B. W., J. Nat. Prod., 70, 307-309 (2007).

8) Zhang D., Yang X., Kang J. S., Choi H. D., Son B. W., J. Nat. Prod., 71, 1458-1460 (2008).

9) Nenkep V. N., Yun K., Li Y., Choi H. D., Kang J. S., Son B. W., J. Antibiot. (Tokyo), 63, 199-201 (2010).

10) Yang G., Yun K., Nenkep V. N., Choi H. D., Kang J. S., Son B. W., Chem. Biodivers., 7, 2766-2770 (2010).

11) Nenkep V. N., Yun K., Zhang D., Choi H. D., Kang J. S., Son B. W., J. Nat. Prod., 73, 2061-2063 (2010).

12) Leutou A. S., Yun K., Choi H. D., Kang J. S., Son B. W., J. Microbiol. Biotechnol., 22, 80-83 (2012).

13) Li X., Kim S.-K., Kang J. S., Choi H. D., Son B. W., J. Microbiol. Biotechnol., 16, 637-638 (2006).

14) Chung H. Y., Choi H. R., Park H. J., Choi J. S., Choi W. C., J. Agric. Food Chem., 49, 3614-3621 (2001), and references cited therein.

15) Ranson M., Br. J. Cancer, 90, 2250-2255 (2004).

16) Jorissen R. N., Walker F., Pouliot N., Garrett T. P., Ward C. W., Burgess A. W., Exp. Cell Res., 284, 31-53 (2003).

17) Stadler M., Anke H., Sterner O., J. Antibiot. (Tokyo), 48, 149-153 (1995).

18) Stadler M., Anke H., Sterner O., J. Antibiot. (Tokyo), 48, 261-266 (1995).

19) Li Y., Li X., Son B. W., Natural Product Sciences, 11, 136-138 (2005). 